\title{
КОНФІГУРАЦІЯ ЯК КОМПОНЕНТ ЖЕСТУ
}

Світлана Кульбіда, Інститут спеціальної педагогіки Національної академії педагогічних наук України, м. Київ, Україна, svk5554@gmail.com

Стаття присвячена вивченню конфрігурації як структурного компонента жесту в українській жестовій мові і є логічним продовженням аналітичних розвідок у галузі структурної лінгвістики 3 питань жестоутворення. Уточено кількість конфігурацій в УЖМ, порівняно 3 кількісними показниками інших жестових мов. Досліджено кожну конфігурацію 3 наданням детального опису та можливого варіанту, зазначено приклади застосування одноручних (дворучних симетричних) жестових одиниць.

Ключові слова: конфігурація, варіант показу, малюнок, лінгвальна категорія, українська жестова мова, опис конфігурації, розміщення долоні (кулака), пальців, жестова одиниця.

Светлана Кульбида, Институт специальной педагогики Национальной академии педагогических наук Украины, г. Киев, Украина

\section{Конфигурация как компонент жеста}

Статья посвящена изучению конфиигурации как структурного компонента жеста в украинском жестовом языке (УЖЯ) и есть логическим продолжением аналитических исследований в отрасли структурной лингвистики по вопросам жестовозникновения. Уточнено количество конфигураций в УЖЯ сравнительно с количественными показателями других жестовых языков. Исследована каждая конфигурация с подробным описанием и возможным вариантом, приведены примеры использования одноручных (двуручных симетричных) жестовых единиц.

Ключевые слова: конфигурация, вариант показа, рисунок, языковая категория, украинский жестовый язык, описание конфигурации, размещение ладони (кулака), направление пальцев, жестовая единица.

Svitlana Kulbida, Institute of Special Education the National Academy of Educational Sciences of Ukraine, Kyiv, Ukraine

\section{Configuration as a component of sign in the Ukrainian Sign Language}

The paper is devoted to the study of configuration as a structural component of the sign in the Ukrainian Sign Language along with localization, direction and character of the movement. The article is a logical continuation of the author's analytical studies in the field of structural linguistics on issues of the signs formation $(2008,2010)$. In the structural analysis of natural sign units the number of configurations in the Ukrainian Sign Language as a sign system are defined and specified from 39 to 40, in comparison with the quantitative indicators of other national Sign Languages, the kinetic features of which were studied earlier. Each configuration with the provision of a drawing image as a basis and a configuration variant is explored. A description of the basic configuration is presented in detail with examples of single-handed and two-handed sign units application.

() Кульбіда С., 2018 
The structural analysis made it possible to understand the features of the configuration location, including the position of the palm (fist), the direction of the finger (fingers), supported by the attached drawings and photos of both single-handed simple (or complex) and two-handed (complex) signs. The study of this issue is important for the theory of the Ukrainian Sign Language structural linguistics and for the practice of using the signs in solving the social problems (the Ukrainian Sign Language interpretation), educational tasks in the modern system of education the deaf and hard of hearing people in Ukraine.

Keywords: configuration, Ukrainian sign language, configuration description, location of fingers, language category, connection movement, disconnection movement, direction of sign.

Актуальність. Упродовж 50 попередніх років відбувалися дослідження різних жестових мов (американської ЖМ, британської ЖМ, ізраїльської ЖМ, німецької ЖМ, японської ЖМ та ін.) з позицій різних дисциплін: антропологія, приматологія, семіотика, соціологія, педагогіка, комп'ютерна техніка, психолінгвістика і когнітивна психологія, мовознавство. Яскравим прикладом на нашу думку лінгвістики стало i вивчення 3 мовознавчих системних позицій фізіологічних аспектів жестів від найменших їх структурних одиниць («фонема», склад, поняття; конфігурація, локалізація, рух тощо). Саме названі лінгвальні категорії у різних жестових мовах давно дають можливість пересвідчитися про описані системи, закономірності, точно так, як і у вербальних мовах, а релевантний інвентар широко застосовується і для вивчення закономірностей національних жестових мов.

Визнання складових жестової одиниці дає змогу враховувати морфофонологічні процеси та обмеження місць у знакових формах (Брентарі 1990, Пельмуттер 1993; Зандлер 1993, Коріна 1996). Підтвердження лінгвальних категорій руху та локалізації (розташування) дає можливість описати процеси інфіксації (Лідделл і Джонсон 1985; Зандлер 1986). Поступову ієрархію функцій забезпечують процеси асиміляції, які спостерігаються у мові (Коріна і Зандлер 1993) $[16,18,19,20,21,24,25]$.

Представлені дослідження лінгвальної структури дають усвідомлене розуміння як подібних, так і відмінних рис між вербальними і жестовими мовами. 3 огляду на зазначене, актуальним нині є системне вивчення особливостей української жестової мови (УЖМ), яка з 2006 року стала предметом, у тому числі, і лінгвального аналізу [3, 9-15].

Мета статmі - на основі відеозразків природного жестового мовлення дослідити жестові одиниці та описати особливості конфігурації - структурної одиниці кінетики УЖМ, як важливого розділу граматики.

Огляд літератури. Першою науковою розвідкою у цьому аспекті стала робота Вільяма Стоку $(1960,1965)$ про системне дослідження структури американської жестової мови (АЖМ).

Три основні й незалежні параметри жестової одиниці - конфігурація руки (handshape), місце показу (локалізація) та рух Стоку називає хіремами (Стоку, Кастерляйн і Кронеберг, 1976). Жести можуть різнитися між собою лише одним 3 цих параметрів, який змінює лексичне значення. Точно так і у вербальній мові ми спостерігаємо зміну одного звука, і відповідно, зміну значення: бік - бак, лис - ліс. 
Термін «хірологія» Стоку трактував як складову граматики, що вивчає найменші значущі частини мовної одиниці [27]. Сучасні вчені застосовують термін «фонологія», який має кілька значень. Пол де Кейсі (2011) пояснює значення узагальненням про звуки та звукові поєднання у різних мовах [16]. В інформаційному довіднику генеративної граматики «фонологія» має відношення до певного когнітивного модуля. Модуль приймає вхідні дані, що складаються 3 рядків фонологіних символів - сегментів, фонем. Символи можуть супроводжуватись інформацією про морфологію, синтаксис. Модуль є основою для провокування руху м'язів і виробляти звуковий сигнал. Як зазначає автор, велика кількість досліджень стверджує, що всі фонологічні модулі мають в основних структурах спільні властивості [26].

Еббі Каплан (2017) припускає на основі теорії прикладів до розуміння мовних систем, що мовне знання не складається з абстрактних узагальнень, а скоріше великої кількості конкретних згаданих лінгвістичних переживань («прикладів»). Кожна мовна одиниця, така як слово, жест складається з хмар зразків [25]. Ці зразки не складаються з (тільки) дискретних абстрактних одиниць, але мають багату фонетичну деталізацію, а також несуть інформацію про позалінгвальний контекст, у якому вони переживалися. Приклади можуть складатися як з однієї, так кількох лексичних одиниць; слова, жести і навіть фрази або висловлювання можуть зберігатися. Узагальнення щодо будь-яких одиниць мови виникають у формі хмар зразків, які можна аналізувати.

Для Стоку члени кожної з цих основних категорій розглядаються як еквівалентні фонемі, але, як і в розмовній мові, пізніші дослідження показали, що особливості кожної категорії мають внутрішню організацію.
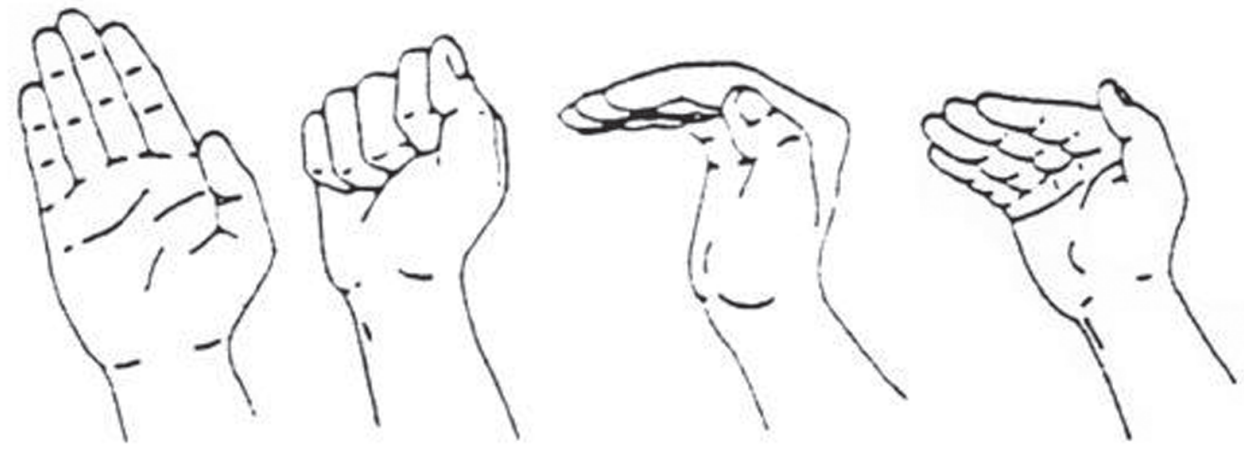

Мал. 1

Приклади конфігурацій, які вибирають усі пальці (ігноруючи великий палець, для простоти) (мал. 1).

У мономорфемному знакові жестова одиниця складається з одного або кількох виділених пальців у певному положенні - розширеному, закритому, вигнутому або зігнутому, що продемонстровано на малюнку. Дослідник Мандель (1981) стверджує, якщо у знаку є зміна губчастого шару, всі обрані пальці змінюють положення таким же чином (Mandel 1981) [26]. Нещодавно дослідження засвідчують, що в деяких далекосхідних жестових мовах є образи, в яких вибрані 
пальці можуть бути в різних позиціях Екаріус (2002), Танг (2007), Фішер і Гунг $(2010,2011)$, часто в результаті запозичення фігур з пальців, нанесених символами вербальної мови або іншими графічними символами [23].

3-поміж трьох незалежних параметрів Стоку та його колеги визначили 19 різних значень конфігурації руки, найпоширенішими з яких є: відкрита пальма, закритий кулак і частково закритий кулак з вказівним пальцем (мал. 2).

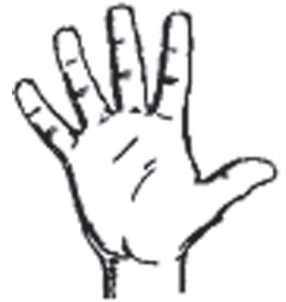

Відкрита пальма

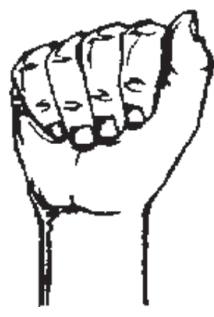

Закритий кулак

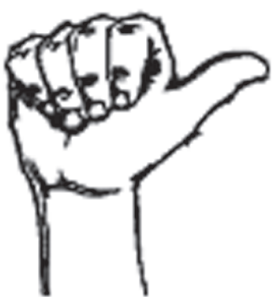

Частково закритий кулак з вказівним пальцем

Мал.2

Особливості орієнтащії, яка визначає положення долоні (кулака), можуть бути контрастними, і дійсно вертикальність і нахиленість називаються особливостями руки в системі позначень, розробленої Стоку (1960) [27]. Дослідник Баттісон (1974) запропонував ввести орієнтацію як четверту основну категорію, зважаючи на:

a) утворення фізіологічних зв'язків між долонею та всією рукою;

б) асиміляційну поведінку, що спостерігається у лексичних з'єднаннях у різних жестових мовах [25].

Інші дослідники - Сандлер $(1987,1989)$ для ізраїльської жестової мови (ІЖМ), Гаррі Хулст (1996) для голландської ЖМ, Сандлер і Лілло-Мартін (2006) для АЖМ і ІЖМ, Куї (2002) для нідерландської мови жестів відображають орієнтацію форми руки, як підлеглу лінгвальну категорію до основної категорії - конфігурація руки [17, 19, 22]. Такої ж позиції дотримуємося і ми.

Вивченню жесту як елементу жестикуляції в УЖМ були присвячені наукові лінгвальні розвідки Н. Адамюк (2009), Н. Зборовської (2007), Н. Іванюшевої (1969, 2004), Р. Краєвського (1964), С. Кульбіди (2010, 2013, 2017), М. Тяжолова (1941), I. Чепчиної $(2008,2011)$ та ін. Зокрема, та Н. Іванюшевою $(1969,2004)$ у тематичних рубриках лексики УЖМ розкрито особливості конфігурацій, локалізацій та характеру руху в природних жестових одиницях [4], Н. Зборовською (2007) представлено аналіз окремих найуживаніших конфігурацій, що використовуються в УЖМ [3]. С. Кульбідою $(2010,2013,2017)$ описано: жест як елемент жестикуляції, локалізацію як компонент жесту в УЖМ $[9,15]$ та представлено системний аналіз трьох конфігурацій

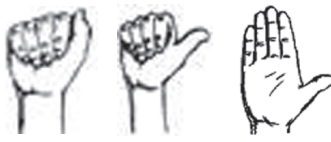

у одноручних і дворучних жестах - для Жестівника УЖМ [5-7].

Виклад основного матеріалу. Структурними компонентами (кінемами) жесту в УЖМ як знакової одиниці є: 
- просторове положення (локалізація, місцерозташування) - таблиця (за У. Стоку);

- конфігурація - дез (за У. Стоку);

- рух - сиг (за У. Стоку) [27].

Структурні компоненти функціонально еквівалентні фонемам у слові, які вибудовуються у морфемі послідовно, на відміну від них у жесті-морфемі одночасно присутні кінеми кожної з трьох позицій. Нині ми знаємо загальну кількість конфігурацій у різних жестових мовах. Зокрема, у Французькій ЖМ 17, Американській жестовій мові (АЖМ) - 19 дезів, Російській ЖМ - 20 і 45 (Зайцева і Димскіс), Німецькій ЖМ - 32, Британській ЖМ - 35, Швецькій ЖМ - 38, Українській ЖМ - 40, Бразильській ЖМ - 44.

Компонент конфігурація характеризується в одноручних жестах положенням пальців та кисті руки, у дворучних жестах - положенням пальців і кисті кожної руки, взаємним розміщенням обох рук.

Конфігурації УЖМ у різних умовах представлені основною позицією, а також наявними варіантами.

Основною вважається конфігурація, коли зміст жесту є чітким і зрозумілим. Вивчені та означені особливості представлені у вигляді табл. 1. До основних 40 основних конфігурацій подано змістовий опис та вказані одноручні та дворучні (симетричні) жестові одиниці.

\begin{tabular}{|c|c|c|c|c|c|}
\hline № & Основна позиція & Варіант & $\begin{array}{c}\text { Oпис } \\
\text { консфігурації }\end{array}$ & $\begin{array}{c}\text { Приклад } \\
\text { одноручних жестів }\end{array}$ & $\begin{array}{c}\text { Приклад } \\
\text { дворучних } \\
\text { жестів }\end{array}$ \\
\hline 1 & & & \begin{tabular}{|l} 
Пальці зібрані в \\
кулак, великий \\
палець притиснутий \\
зліва до вказівного \\
пальця
\end{tabular} & $\begin{array}{l}\text { АБСУРД, БАБУСЯ, } \\
\text { ВІЙСЬКОВИЙ, } \\
\text { ДАРНИЦЯ, ЗЛІСТЬ, } \\
\text { МІКРОФОН, } \\
\text { ПАМ'ЯТАТИ, } \\
\text { ПЕРЕМОГА, } \\
\text { СЕРЦЕБИТТ,, } \\
\text { СТАРИЙ, ШТАМП } \\
\text { Та ї. }\end{array}$ & $\begin{array}{l}\text { ВЕРБЛЮД, } \\
\text { ЗАХИСТ, } \\
\text { РОБОТА, } \\
\text { ШАПКА, } \\
\text { ХОДИТИ НА } \\
\text { ЛИЖАХ }\end{array}$ \\
\hline 2 & & & $\begin{array}{l}\text { Усі пальці зібрані } \\
\text { в кулак, окрім } \\
\text { великого пальця, } \\
\text { який відведений } \\
\text { вбік }\end{array}$ & $\begin{array}{l}\text { ДОБРО } \\
\text { (СХВАЛЕННЯ), II'Я, } \\
\text { ЛЕДАР, МІСЯЦЦЬ } \\
\text { НАТИСНУТИ, } \\
\text { ПЕРШИИ,, } \\
\text { ПРИСУТНИИ, РІК, } \\
\text { САЛО, СПОКІЙ, } \\
\text { ТИЖДЕНЬ та ін. }\end{array}$ & $\begin{array}{l}\text { БЕНЗИН, } \\
\text { БЛИЗНЮКИ, } \\
\text { ЇДАЛЬНЯ, } \\
\text { СМАЧНОГО, } \\
\text { ПРЕЗИДІЯ }\end{array}$ \\
\hline 3 & & & $\begin{array}{l}\text { Вказівний огортає } \\
\text { випрямлений } \\
\text { великий палець, } \\
\text { інші - притиснуті } \\
\text { до долоні }\end{array}$ & $\begin{array}{l}\text { ГОДУВАТИ, ЗАВУЧ, } \\
\text { МАЛЮВАТИ, } \\
\text { ПОДАРУВАТИ, } \\
\text { ЧАСНИК, ЧОЛОВІК } \\
\text { та ін. }\end{array}$ & $\begin{array}{l}\text { КЕРУВАТИ, } \\
\text { ПЕРЕВIРКА, } \\
\text { TOРГІВЛЯ, } \\
\text { TЯГНУТИ ЗА } \\
\text { ВУХА }\end{array}$ \\
\hline
\end{tabular}




\section{[NAVTA}

\begin{tabular}{|c|c|c|c|c|c|}
\hline 4 & & & \begin{tabular}{|l|} 
Вказівний палець \\
випрямлений вперед \\
і підтримуються \\
випрямленим \\
великим пальцем, \\
інші - притиснуті \\
до долоні \\
\end{tabular} & $\begin{array}{l}\text { ВИБИТИСЯ } 3 \text { СИЛ, } \\
\text { КОМАР, КУРКА, та } \\
\text { iн. }\end{array}$ & КЛЮВАТИ \\
\hline 5 & & & \begin{tabular}{|l|} 
Вказівний палець \\
випрямлений вперед \\
і знаходиться \\
над випрямленим \\
великим пальцем, \\
інші - притиснуті \\
до долоні
\end{tabular} & ПОНЕДІЛОК, ПТАШКА & $\begin{array}{l}\text { ПРОСИНАТИСЯ, } \\
\text { ВІДКРИВАТИ } \\
\text { РОТ }\end{array}$ \\
\hline 6 & & & \begin{tabular}{|l|} 
Вказівний палець \\
напівзігнутий вперед \\
і підтримуються \\
напівзігнутим \\
великим пальцем, \\
інші - притиснуті \\
до долоні \\
\end{tabular} & $\begin{array}{l}\text { ВИТЯГУВАТИ, } \\
\text { ДРІБНИЦЯ, ЗЕРНО, } \\
\text { ВИШИВАТИ та ін. }\end{array}$ & \\
\hline 7 & & & \begin{tabular}{|l|} 
Вказівний палець \\
випрямлений вперед \\
і підтримуються \\
випрямленим \\
великим пальцем, \\
інші - випрямлені \\
вгору
\end{tabular} & $\begin{array}{l}\text { НИТКА, ПОСТІЛЬ, } \\
\text { ТОНКИЙ, СІЛЬ, } \\
\text { ХУДИЙ та ін. }\end{array}$ & $\begin{array}{l}\text { ЛАНЦЮГ, } \\
\text { РЕЧЕННЯ }\end{array}$ \\
\hline 8 & & & \begin{tabular}{|l|} 
Нігтьову фралангу \\
напівзігнутого. \\
вказівного пальця \\
закриває великий \\
палець, інші пальці \\
випрямлені вгору і \\
не з'єднуються
\end{tabular} & $\begin{array}{l}\text { ВІДСОТОК, ЗГАДАТИ, } \\
\text { НІЧОГО, НУЛЬ, } \\
\text { ОСТРІВ, } \\
\text { ПРАВДА, } \\
\text { ПРАВИЛЬНО, } \\
\text { РАНО, та ін. }\end{array}$ & $\begin{array}{l}\text { СТРІЛЯТИ } \\
\text { ОЧИМА, } \\
\text { ШАЛЕНО }\end{array}$ \\
\hline 9 & 0 & ses & \begin{tabular}{|l|} 
Долоня звернена \\
до співесідника, \\
всі пальці підняті \\
вгору, рівні та \\
3'єднані між \\
собою (великий \\
палець може бути \\
від'єнаним від \\
долоні, приєнаним \\
до долоні)
\end{tabular} & $\begin{array}{l}\text { БАТЬКИ, БУДЕ, } \\
\text { ВЕСЕЛО, ДІТИ, } \\
\text { ДОСТАТНЬО, } \\
\text { ЗАДИРАТИ НОСА, } \\
\text { БАТЬКО, МАТІР, } \\
\text { ЯЗИК ДО КИЄВА } \\
\text { ДОВЕДЕ та ін. }\end{array}$ & $\begin{array}{l}\text { ЖИТТЯ, } \\
\text { МІЖ ТИМ, } \\
\text { ПАДАТИ } \\
\text { ДУХОМ, } \\
\text { ПАДАТИ } 3 \\
\text { НІГ, ПОВІТЯ, } \\
\text { ПРИБЛИЗНО, } \\
\text { ТЕПЛА } \\
\text { КОМПАНІЯ, } \\
\text { ТРИМАТИСЯ ЗА } \\
\text { ЖИТТЯ }\end{array}$ \\
\hline
\end{tabular}




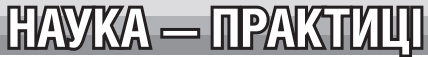

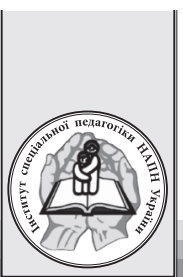

Продовження

\begin{tabular}{|c|c|c|c|c|c|}
\hline 10 & 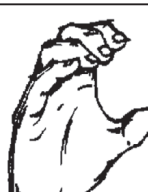 & 3 & $\begin{array}{l}\text { Усі пальці } \\
\text { напівзігнуті } \\
\text { таким чином, що } \\
\text { утворюють контур } \\
\text { літери C }\end{array}$ & $\begin{array}{l}\text { ПИТИ, СЕРЕДА, } \\
\text { СИНІИ та ін. }\end{array}$ & $\begin{array}{l}\text { ЗНАЙОМСТВО, } \\
\text { СТАДІОН }\end{array}$ \\
\hline 11 & & & $\begin{array}{l}\text { Усі пальці } \\
\text { напівзігнуті і } \\
\text { роз'єднані таким } \\
\text { чином, що } \\
\text { утворюють контур } \\
\text { літери С }\end{array}$ & $\begin{array}{l}\text { БЕГЕМОТ, ГАРЯЧИЙ, } \\
\text { М'ЯЧ, ФОТОАПАРАТ, } \\
\text { ЯБЛУКО та ін. }\end{array}$ & $\begin{array}{l}\text { СВІТ, } \\
\text { СКУПИЙ, } \\
\text { ТУРБОТА }\end{array}$ \\
\hline 12 & & & $\begin{array}{l}\text { Всі пальці підняті } \\
\text { вгору, рівні та } \\
\text { роз'єднані між } \\
\text { собою }\end{array}$ & $\begin{array}{l}\text { ВЖЕ, ВИПАДОК, } \\
\text { ГУЛЯЯИ, КАВКАЗ, } \\
\text { КОЛИ, П'ЯТЬ, } \\
\text { РАХУВАТИ, СІМ'Я, } \\
\text { СКІЛЬКИ, СЛІПОТА, } \\
\text { ТІСТЕЧКО, ЧАС та ін. }\end{array}$ & $\begin{array}{l}\text { ВІДПОЧИВАТИ, } \\
\text { ВІТЕР, ДОЩ } \\
\text { ЛЛЄ, КУЩІ, } \\
\text { СЕЛО, } \\
\text { СЕРЕДНІЙ, } \\
\text { СЛАБКІСТЬ }\end{array}$ \\
\hline 13 & a & & $\begin{array}{l}\text { Усі пальці підняті } \\
\text { та роз'єднані між } \\
\text { собою, середній } \\
\text { палець дещо } \\
\text { виступає вперед }\end{array}$ & $\begin{array}{l}\text { ЛІТО, МАНДРУВАТИ, } \\
\text { МАТИ НА } \\
\text { МЕТІ, МЕТА, } \\
\text { НЕГРАМОТНИЙ, } \\
\text { ОГИДНИЙ, } \\
\text { СЕРЦЕ, СУРОВИЙ, } \\
\text { ТЕЛЕГРАМА, ЦЕНТР } \\
\text { та ін. } \\
\end{array}$ & $\begin{array}{l}\text { AРТИСТ, } \\
\text { IHТЕРНЕТ, } \\
\text { TEATP }\end{array}$ \\
\hline 14 & & & \begin{tabular}{|l} 
Нігтьову фалангу \\
напівзігнутого сер. \\
пальця закриває \\
великий палець, \\
інші пальці \\
випрямлені вгору і \\
не з'єднуються
\end{tabular} & $\begin{array}{l}\text { ЗНЕНАЦЬКА, КЛЕЙ, } \\
\text { НЕРВИ, РЕСТОРАН, } \\
\text { РАЙОН, РОЖЕВИЙ, } \\
\text { та ін. }\end{array}$ & $\begin{array}{l}\text { РОЗПОВІДАТИ, } \\
\text { ШУМ }\end{array}$ \\
\hline 15 & & & $\begin{array}{l}\text { Мізинець і великий } \\
\text { пальці підняті } \\
\text { рівно вгору; } \\
\text { вказівний, середній } \\
\text { і безіменний пальці } \\
\text { притиснуті до } \\
\text { долоні }\end{array}$ & $\begin{array}{l}\text { ЗДИВОВАНІСТЬ, } \\
\text { ЗЛИВАТИ, КУДИ, } \\
\text { ЛАБОРАТОРІЯ, ОЛІЯ, } \\
\text { ПРАСКА, СУБОТА, } \\
\text { ХУЛІГАН та ін. }\end{array}$ & 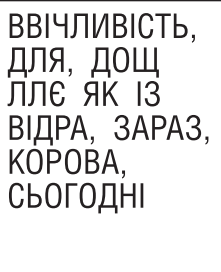 \\
\hline 16 & & 9 & $\begin{array}{l}\text { Мізинець і } \\
\text { вказівний пальці } \\
\text { підняті рівно } \\
\text { вгору; середній і } \\
\text { безіменний пальці } \\
\text { притиснуті до } \\
\text { долоні великим } \\
\text { пальцем }\end{array}$ & $\begin{array}{l}\text { BІКНО, ЛІТАК, } \\
\text { КАПЕЛЮХ, КОСТЮМ, } \\
\text { ДИТИНА, КРУТИЙ, } \\
\text { КРУГЛИЙ СТІЛ, } \\
\text { ВПЕРТІСТЬ та ін. }\end{array}$ & $\begin{array}{l}\text { ВІКНА, } \\
\text { МИЛИЦІ }\end{array}$ \\
\hline
\end{tabular}




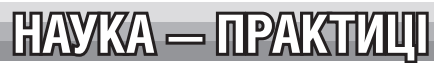

\begin{tabular}{|c|c|c|c|c|c|}
\hline 17 & of & & \begin{tabular}{|l} 
Мізинець і \\
вказівний пальці \\
підняті рівно \\
вгору; середній і \\
безіменний пальці \\
випрямлені вперед \\
і накладаються на \\
великий палець
\end{tabular} & $\begin{array}{l}\text { ЛІЖКО, СПАЛЬНЯ, } \\
\text { СТІЛЕЦЦЬ Та ін. }\end{array}$ & $\begin{array}{l}\text { ЛІЖЖKА, } \\
\text { IHTEPHAT }\end{array}$ \\
\hline 18 & & & \begin{tabular}{|l|} 
Нігтьову фалангу \\
напівзігнутого \\
безіменного пальця \\
закриває великий \\
палець, інші пальці \\
випрямлені вгору і \\
не з'єднуються
\end{tabular} & $\begin{array}{l}\text { ГОРЕ, ВИКОРИСТАТИ } \\
\text { ДІВЧИНУ, } \\
\text { ЗАЛИШИТИСЯ, } \\
\text { КНЯЗЬ, } \\
\text { НЕНОРМАЛЬНИЙ,та } \\
\text { ін. }\end{array}$ & $\begin{array}{l}\text { HEПОТРІБHO, } \\
\text { HIЖHICTЬ, } \\
\text { ПОСТІИНО, } \\
\text { ПОTPIБHO }\end{array}$ \\
\hline 19 & & & \begin{tabular}{|l|} 
Чотири пальці: \\
від мізинця - до \\
вказівного підняті \\
вгору, рівні \\
(напівзігнуті) та \\
роз'єднані між \\
собою, великий \\
палець притиснений \\
до долоні \\
\end{tabular} & $\begin{array}{l}\text { ВІЇ, ВІЯЛО, КЛІПАТИ, } \\
\text { НАЧАЛЬНИК, СІРИЙ, } \\
\text { ЧОТИРИ та ін. }\end{array}$ & ВСТАТИ В КОЛО \\
\hline 20 & & & $\begin{array}{l}\text { Великий, вказівний } \\
\text { та середній пальці } \\
\text { роз'єднані та } \\
\text { випрямлені, інші - } \\
\text { притиснуті до } \\
\text { долоні }\end{array}$ & $\begin{array}{l}\text { КВАРТАЛ, ТРИ, } \\
\text { ТРИДЦЯТЬ, ТРИ ДНІ } \\
\text { ТОМУУ, ТРИ МІСЯЦ̈, } \\
\text { ЧЕРЕЗ ТРИ РОКИ } \\
\text { та ін. }\end{array}$ & \\
\hline 21 & & & $\begin{array}{l}\text { Вказівний, середній } \\
\text { і великий пальці } \\
\text { рівні, з’єднані між } \\
\text { собою, інші пальці } \\
\text { зігнуті в долоні }\end{array}$ & $\begin{array}{l}\text { ДУЕЛЬ, ЗБРОЯ, ТАК } \\
\text { (кальК.) та ін. }\end{array}$ & \\
\hline 22 & & & $\begin{array}{l}\text { Великий, вказівний } \\
\text { та середній пальці } \\
\text { роз'єднані та } \\
\text { напівзігнуті, інші - } \\
\text { притиснуті до } \\
\text { долоні }\end{array}$ & $\begin{array}{l}\text { ГРЕЧКА, СУМНО, } \\
\text { ТРИСТА, ДУЖЕ } \\
\text { БОЛИТЬ та ін. }\end{array}$ & \\
\hline 23 & & 60.0 & \begin{tabular}{|l|} 
Вказівний,середній і \\
безіменний пальці \\
Розз'єднані між \\
собою, мізинець \\
притиснутий до \\
долоні великим \\
пальцем
\end{tabular} & $\begin{array}{l}\text { ВИДЕЛКА, МІЛЬЙОН, } \\
\text { МІНІСТЕРСТВО, } \\
\text { МЕТРО, МОДА, } \\
\text { ЗАРПЛАТА, } \\
\text { ПОЖЕЖА, та ін. }\end{array}$ & \\
\hline
\end{tabular}




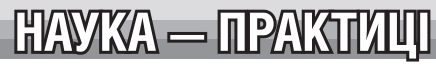

Продовження

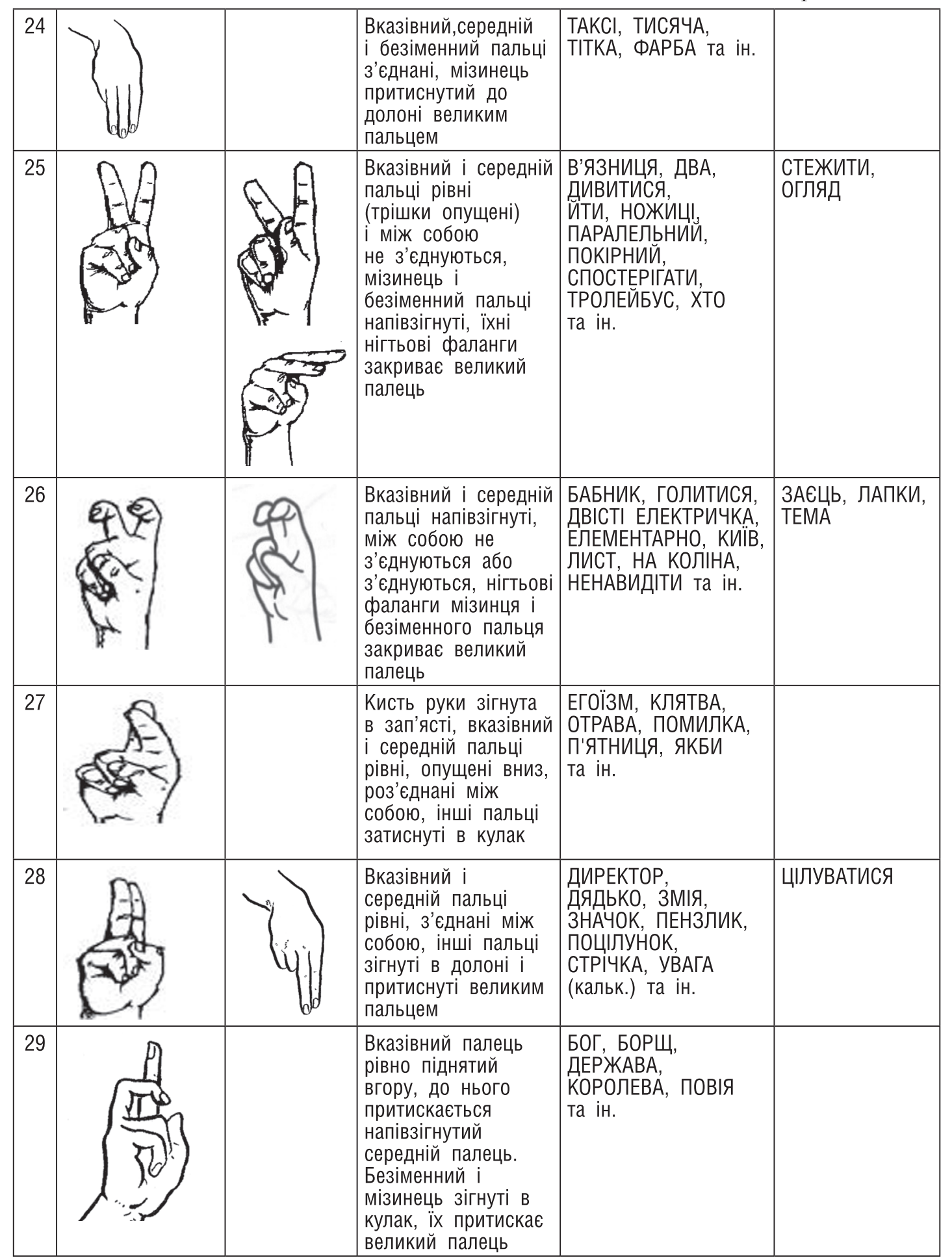


Продовження

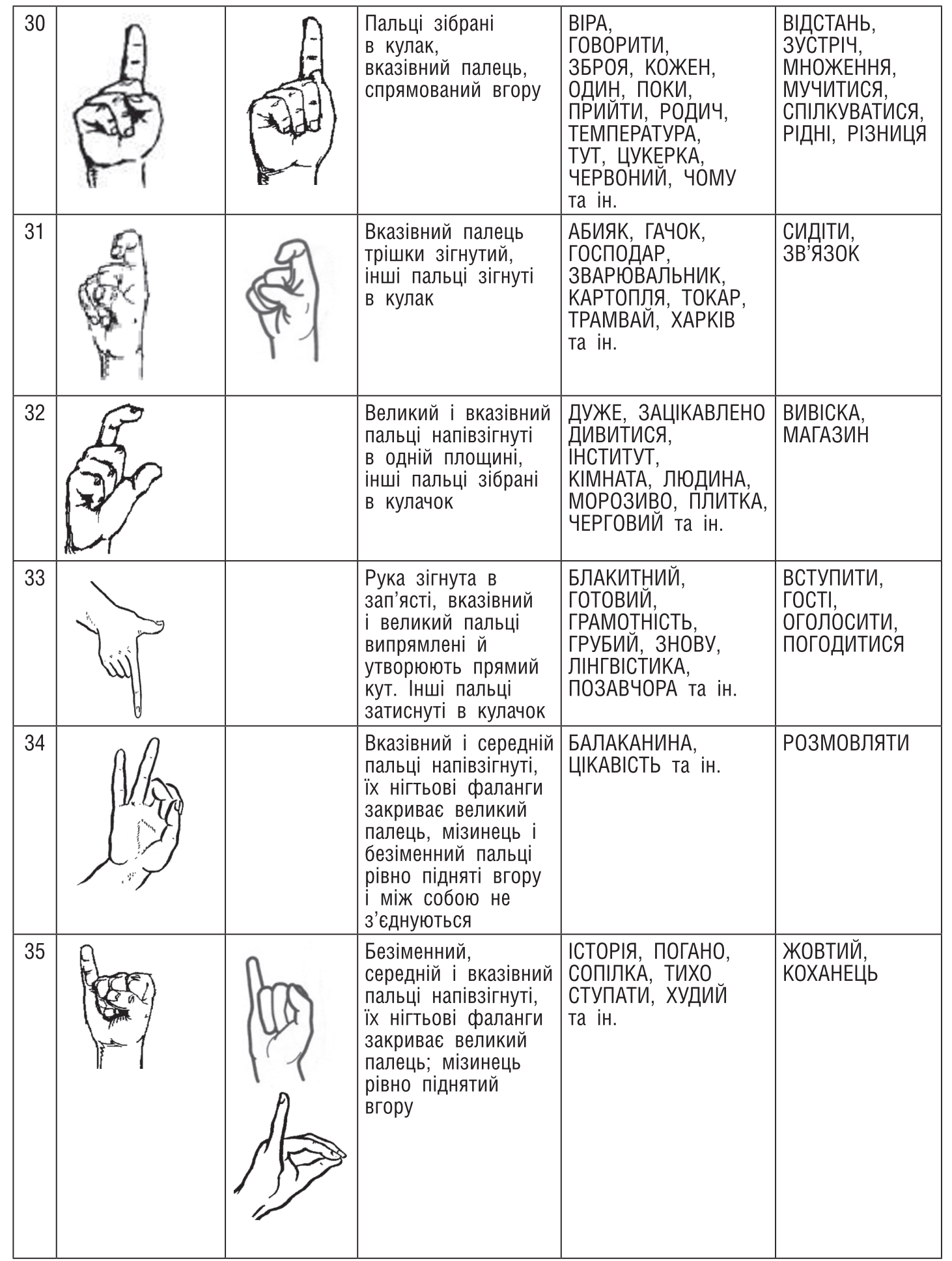




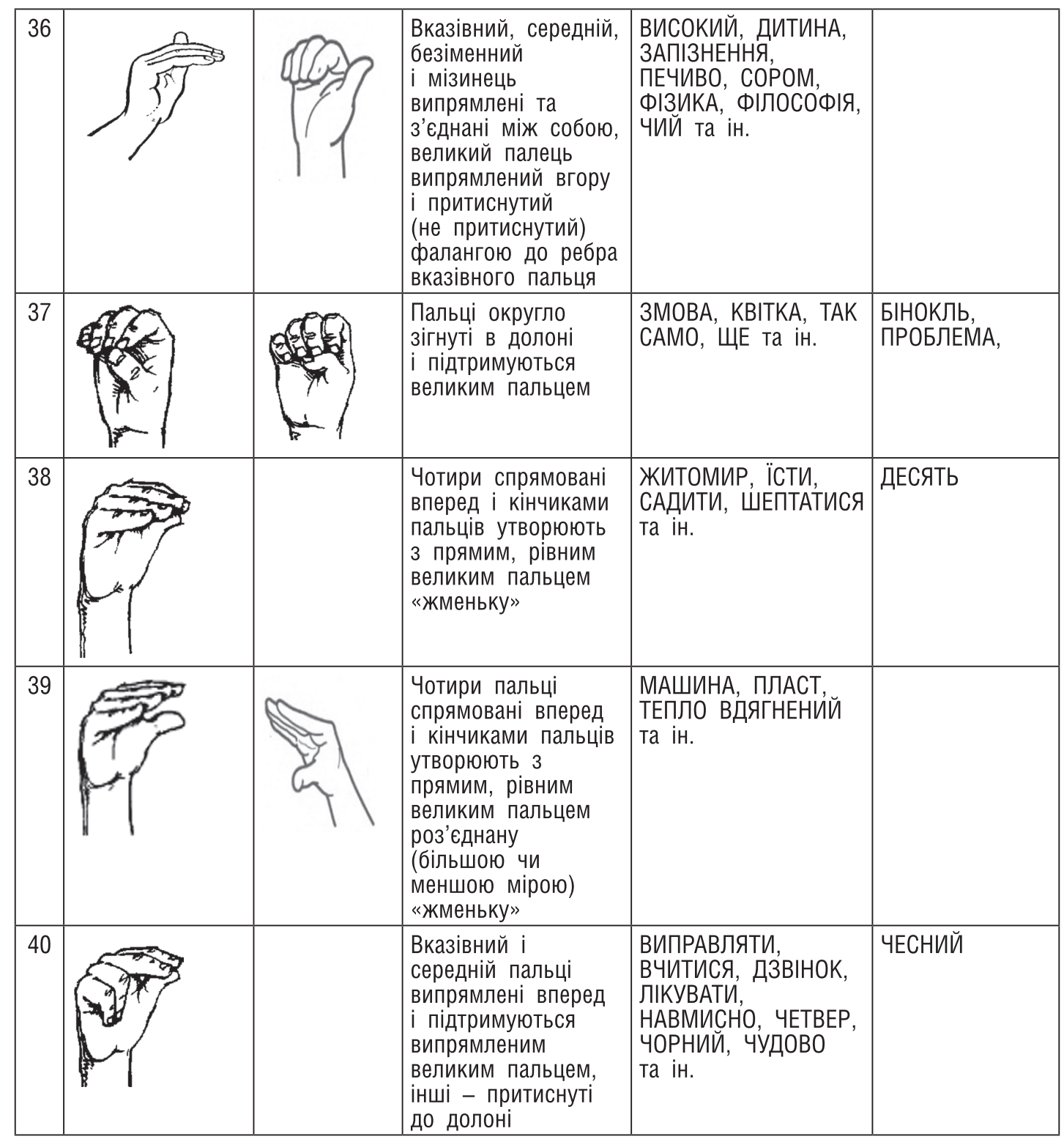


23 конфігурації мають варіанти показу (№ 1, 3-6, 8-10, 12, 14, 16, 19, 23, $25,26,28,30,31,35-37,39)$, але зміст жестової одиниці від цього не змінюється [11, 12]. Таку ж особливість спостерігаємо у писемній формі словесної мови, коли фонеми потрібно передати графемами, які реалізуються різними писаними літерами: с і C (маленька або велика літери), т і т (друкована або писана літера), але у всіх варіантах зберігається визначена спільність.

Доречно звернути увагу на форму руки у конфігурації як важливий момент фіксації жестової одиниці, необхідної для правильного показу і кодування (запису) та сприймання і декодування (зчитування). Форма руки складається із двох частин: положення долоні (кулака), напрямок пальця(ів). Для прикладу конфігурація № 3 у наступній таблиці одноручних простих жестів демонструє як основну конфігурацію ff⿰耳, , (фото 1, 3, 5), iї варіанти (фото 2,4), так і положення долоні і напрям "

Основна конфігурація № 3, ї̈ варіанти, положення долоні і напрям пальців в одноручних простих жестах

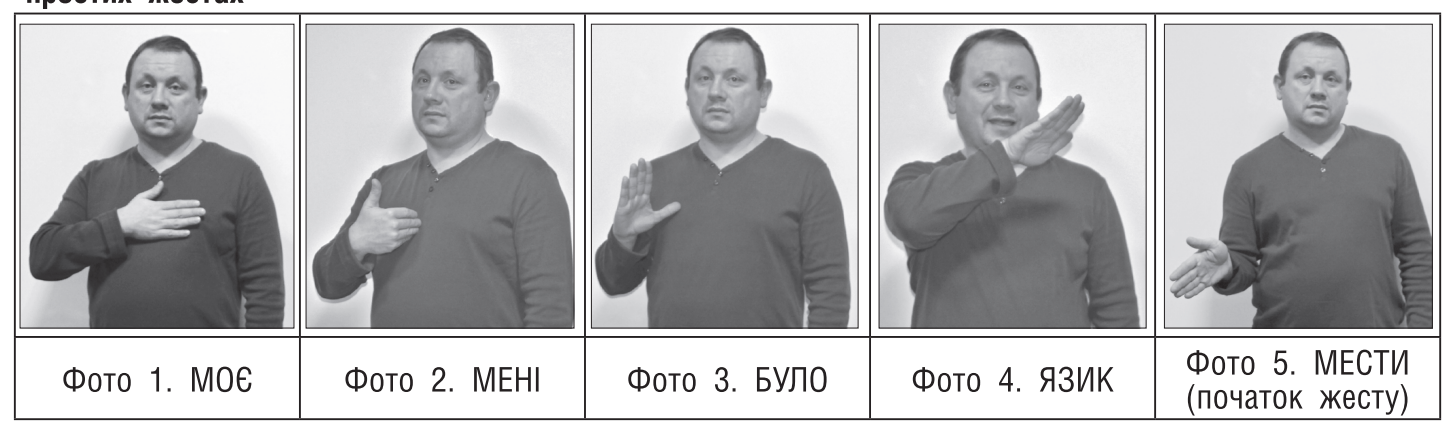

Українська дослідниця Н. Зборовська (2009) зазначає, що положення долоні у жестах ЗАВАЖАТИ (фото. 6) і СЛЮСАР (фото 7) використовується однакова конфігурація, але при показі першого жесту ЗАВАЖАТИ долоня спрямована ліворуч, а при другому - СЛЮСАР - донизу, що є важливим для точності відтворення кожної жестової одиниці. Жести ЧУТИ і ВІДЧУТИ (мал. 1, 2) при застосуванні однакової конфігурації демонструють різне положення руки та вказівного пальця до певного об’єкта (вуха, зовнішнього боку
пасивної руки) [3].

На прикладі жестів (фото 8, фото 9) спостерігаємо різне положення кулака - убік ПИЛКА і до співбесідника-донизу ПИВО [5]. 


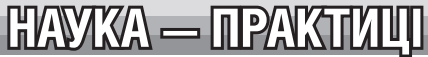
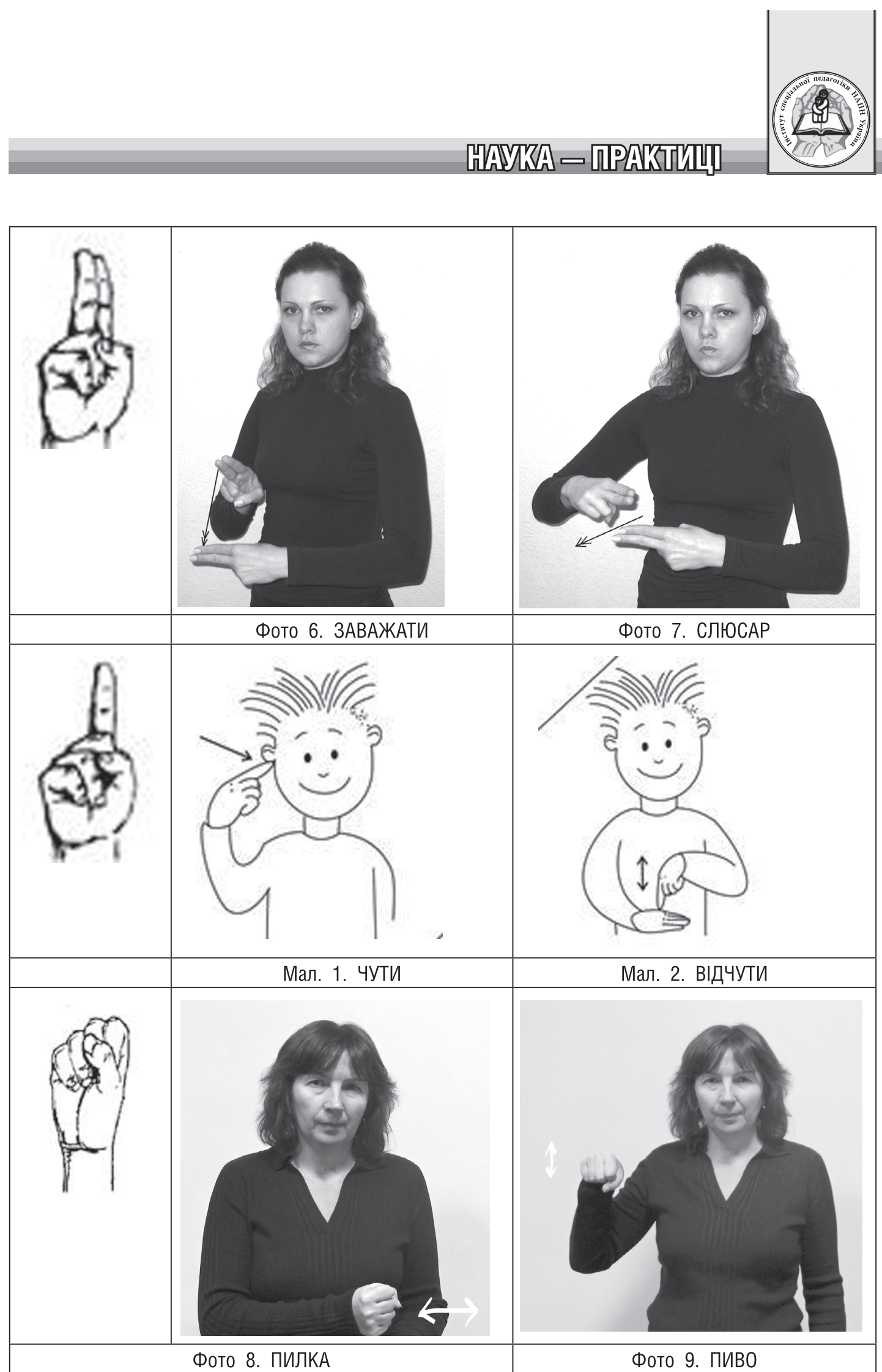
Подібну особливість відмітила білоруська дослідниця Л. Димскис (2002) у РЖМ (російській жестовій мові) на прикладі застосування конфігурації (f⿴囗十⺝, ,

коли напрям пальців змінюється у одноручних простих жестах ЛITO і TAТО $[2,4]$.

Застосування двох конфігурацій в одній жестовій одиниці явище поширене у всіх національних жестових мовах. В УЖМ також спостерігаємо у таких складних жестах:

- одноручних ВІДОМИЙ, ПОПУЛЯРНИЙ (мал. 3), ГАРНО (фото 12), ГРЕЧКА, ДВІСТІ, ЗНЕСИЛЕННЯ, НЕ ВИХОДИТЬ 3 ГОЛОВИ, ОДИНАДЦЯТЬ, КВІТКА, ПОМИЛКА, СТО, ТАК (фото 10-11), ЩЕ та ін.;

- дворУчних БРИГАДИР, ДАТИ (мал. 4), ВЗЯТИ (мал. 5), ЗАВДАННЯ, КЛЕЙ, КОВДРА (фото 13), КОРДОН (фото 14), РОЗПОВІДАТИ, ЩАСТЯ та ін.

\section{Застосування двох конфігурацій в одній жестовій одиниці} ОДНОРУЧНІ СКЛАДНІ:

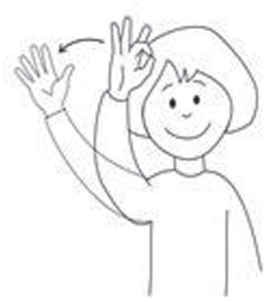

Мал. 3. ВІДОМиЙ, ПОПУЛЯРНИЙ

ДВОРУЧНІ СКЛАДНІ:

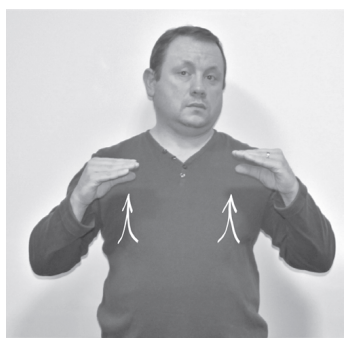

Фото 13. КОВДРА

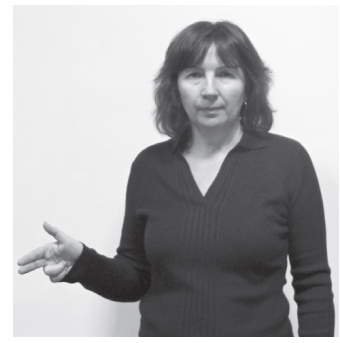

Фото 10. ТАК (початок)

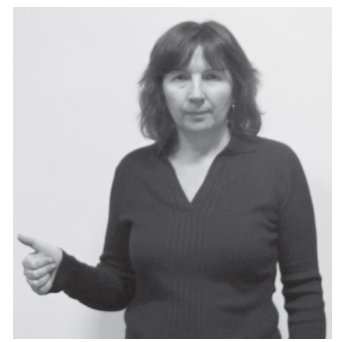

Фото 11. ТАК (продовження)

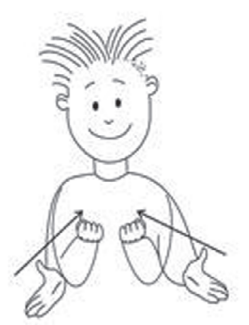

Мал. 5. Взяти

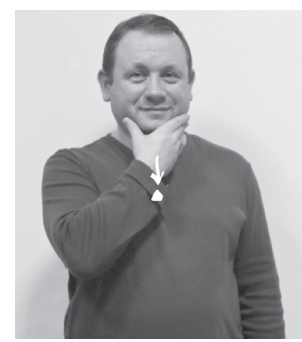

Фото 12. ГАРНО

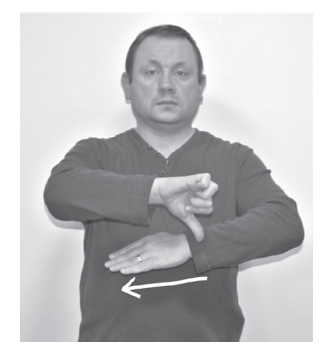

Фото 14. КОРДОН

Висновки. У представленому дослідженні продемонстровано зразок застосування лінгвальних категорій як релевантногого інструментарію зарубіжних учених для кінетичного аналізу елементу «конфігурація» в УЖМ аналізу інших жестових мов. Отже, в УЖМ нараховуємо 40 конфігурацій, у 23 конфігураціях спостерігаємо варіанти показу. На прикладах жестових одиниць, представлених на фото Зборовської Н., Кульбіди С., Федорченка Д. та малюнках проде- 


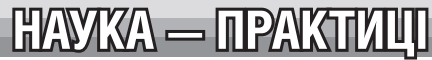

монстровано, що кожна з конфігурацій характеризується особливістю побудови (положенням долоні чи кулака, спрямуванням пальця чи пальців).

Подальші лінгвальні розвідки з питань кінетики слугуватимуть уточненню релевантного інвентарю для вивчення жестових одиниць і сприятиме зростанню нашого розуміння природних жестів, а саме у питанні про те, в який спосіб УЖМ, як мова, виробляється, сприймається, впливає на ії основну кінетичну структуру.

\section{ЛITEPATУPA}

1. Географічний жестівник: континенти, країни, міста. - С. Кульбіда, І. Чепчина, Н. Адамюк, В. Кириченко. - Посібник. - Київ: СПКТБ УТОГ. -2014. - 96 с.

2. Димскис ЛI .С. Изучаем жестовый язык. ЛІ. Димскис. Пособие. Минск.- 2002. С. 4.

3. Зборовська Н. А. Особливості лінгвістичного дослідження української жестової мови у доробку Р. Г. Краєвського, Н. Зборовська, С. Кульбіда // Жестова мова й сучасність : Зб. наукових праць. - Вип. 2- Київ. -2007.- С.197 - 210.

4. Иванюшева Н. В. Мимико-жесткуляторная речь. Н. Иванюшева. Учебное пособие. - К., 1969. $-249 \mathrm{c}$.

5. Кінетичні особливості української жестової мови. Частина перша. С. Кульбіда. Жестівник «Українська жестова мова». Режим доступу http://lib.iitta.gov.ua/707284/.

6. Кінетичні особливості української жестової мови. Частина друга. С. Кульбіда. Жестівник «Українська жестова мова». Режим доступу http://lib.iitta.gov.ua/707467/.

7. Кінетичні особливості української жестової мови. Частина третя. С. Кульбіда. Жестівник «Українська жестова мова». Режим доступу http://lib.iitta.gov.ua/707468/.

8. Краєвський Р. Г. Мова жестів глухих. К. : Радянська школа, 1964.

9. Кульбіда С. В. Дотримання мовленнєвої норми при опануванні дактилем нечуючими учнями. / С Кульбіда./ Психолого-педагогічний супровід дітей з порушеннями слуху та інтелекту / За ред. В. І. Бондаря, В. В. Засенка. - К.: Тов. «Поліпром».- 2007. - С. 65 - 76.

10. Кульбіда С. В. Жест як елемент жестикуляції. Локалізація - компонент жесту / С. В. Кульбіда // Жестова мова й сучасність: збірник наукових праць. - 2010. - Вип. 5. C. 159 - 175. Режим доступу : http://lib.iitta.gov.ua/1980/

11. Кульбіда С. В. Жест як основний компонент жестової мови. С. Кульбіда.-Жестова мова й сучасність : зб. наук. праць. - К.: Науковий світ, 2010. - Вип. 5. - С. 159 - 175.

12. Кульбіда С. В. Теоретико-методичні засади використання жестової мови у навчанні нечуючих : монографія / С. В. Кульбіда. - К. : Поліпром, 2010. - 503 с.

13. Українська дактилологія : науково-методичний посібник. - С. Кульбіда. - К.: Педагогічна думка, 2007. - 328 с.

14. Український жестівник для батьків. Жестівник. - НАПН України, Ін-т спец. педагогіки, Лаб. Жестової мови, Укр. т-во глухих. - К.: СПКТБ УТОГ, 2011. - 380 с.

15. Українська жестова мова. Жестівник : навчальний посібник / С. Кульбіда, I. Чепчина, Н. Адамюк. - К.: [Педагогічна думка], 2012. - 206 с.

«ОСОБЛИВА ДИТИНА: навчання і виховання», № 4, 2018 
16. Брентарі Діана. Знак мови фонології. Довідник фонологічної теорії. Вілей-Блеквелл; Hoboken, NJ: 2011b. с. 691-721.

17. Kooij Else van der. Канд. дисертація. Лейденський університет; 2002 р. Фонологічні категорії в мові жестів Нідерландів: роль фонетичної реалізації та іконічності.

18. Лідделл Скотm K., Джонсон Роберт E. Американська мова мови: фонологічна база. Вивчення мовних знаків 1989; 64 : 195-277.

19. Сандерл Венді. Фонологія, фонетика та бездоганна рука. Мутон де Грюйтер; Берлін: 2005 p. $185-212$.

20. Падден Карол, Перлмуттер Девід М. Американська мова жестів та архітектура фонологічної теорії. Природна мова та мовна теорія. 1987; 5 : 335-375.

21. Raithel, 2000. Режим доступу: http://www.uni-bielefeld.de/lili/personen/vraithel/ teaching/ial/sign-language.pdf

22. Хулст Гаррі ван дер. Одиниці аналізу знаків. Фонологія. 1993; 10 : 209-41.

23. Фішер Съюзен, Гонг Куньху. Позначені ручні конфігурації в азіатських мовах мови. У: Кансон Рейчел, ван Гаррі дер Хулст., Формаційні одиниці за ознакою мови. Т. 3. Ishara

24. Швецькі конфігурації Режим доступу: http://www.teckensprak.com/handformer.html

25. Modality and Structure in Signed and Spoken Languages, 2009

26. Variation in handshape and orientation in British Sign Language: The case of the ' 1 ' hand configuration.

27. William C. Stokoe, Dorothy C. Casterline, Carl G. Croneberg Linstok Press, 1976 -346 p.

\section{REFERENCES (TRANSLATED AND TRANSLITERATED)}

1. Heohrafichnyi zhestivnyk: kontynenty, krainy, mista. - S. Kulbida, I. Chepchyna, N. Adamiuk, V.Kyrychenko. - Posibnyk. - Kyiv: SPKTB UTOH. 2014. - 96 s.

2. Dymskys L.S. (2002) Yzuchaem zhestovыi yazыk. L. Dymskys. Posobye. Mynsk. - S. 4.

3. Zborozska N.A.( 2007) Osoblyvosti linhvistychnoho doslidzhennia ukrainskoi zhestovoi movy u dorobku R.H.Kraievskoho.- N. Zborovska, S. Kulbida.- Zhestova mova y suchasnist : Zb. naukovykh prats. - Vyp. 2.- Kyiv, S.197 - 210.

4. Yvaniusheva N.V. Mymyko-zhestkuliatornaia rech. Natalyia Yvaniusheva. Uchebnoe posobye. - K., 1969. - $249 \mathrm{~s}$.

5. Kinetychni osoblyvosti ukrainskoi zhestovoi movy. Chastyna persha. S. Kulbida. Zhestivnyk "Ukrainska zhestova mova". Rezhym dostupu http://lib.iitta.gov.ua/707284/.

6. Kinetychni osoblyvosti ukrainskoi zhestovoi movy. Chastyna druha. S. Kulbida. Zhestivnyk "Ukrainska zhestova mova". Rezhym dostupu http://lib.iitta.gov.ua/707467/

7. Kinetychni osoblyvosti ukrainskoi zhestovoi movy. Chastyna tretia. S. Kulbida. Zhestivnyk "Ukrainska zhestova mova". Rezhym dostupu http://lib.iitta.gov.ua/707468/

8. Kraievskyi R.H. (1964) Mova zhestiv hlukhykh. K. : Radianska shkola.

9. Kulbida S.V. Dotrymannia movlennievoi normy pry opanuvanni daktylem nechuiuchymy uchniamy. S. Kulbida.-Psykholoho-pedahohichnyi suprovid ditei z porushenniamy slukhu ta intelektu / Za red. V. I. Bondaria, V.V. Zasenka. - K.: Tov. „Poliprom”; 2007. - S. 65 - 76. 


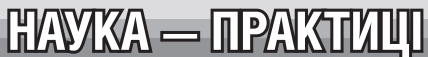

10. Kulbida S.V. Zhest yak element zhestykuliatsii. Lokalizatsiia - komponent zhestu / S. V. Kulbida // Zhestova mova y suchasnist: zbirnyk naukovykh prats. - 2010. - Vyp. 5. C. 159 - 175. Rezhym dostupu : http://lib.iitta.gov.ua/1980/

11. Kulbida S.V. Zhest yak osnovnyi komponent zhestovoi movy. S. Kulbida.-Zhestova mova y suchasnist : zb. nauk. prats. - K.: Naukovyi svit, 2010. - Vyp. 5. - S. $159-175$.

12. Kulbida $S$. V. Teoretyko-metodychni zasady vykorystannia zhestovoi movy u navchanni nechuiuchykh : monohrafiia / S. V. Kulbida. - K. : Poliprom, 2010. -503 c.

13. Ukrainska daktylolohiia: naukovo-metodychnyi posibnyk. - S. Kulbida. - K.: Pedahohichna dumka, 2007. $-328 \mathrm{~s}$.

14. Ukrainskyi zhestivnyk dlia batkiv. Zhestivnyk. - NAPN Ukrainy, In-t spets. pedahohiky, Lab. Zhestovoi movy, Ukr. t-vo hlukhykh. - K.: SPKTB UTOH, 2011. - 380 s.

15. Ukrainska zhestova mova. Zhestivnyk : navchalnyi posibnyk / S.Kulbida, I.Chepchyna, N.Adamiuk. - K.: [Pedahohichna dumka], 2012. - 206 s.

16. Brentari Diana. Znak movy fonolohii. Dovidnyk fonolohichnoi teorii. VileiBlekvell; Hoboken, NJ: 2011b. s. 691-721.

17. Kooij Else van der. Kand. dysertatsiia. Leidenskyi universytet; 2002 r. Fonolohichni katehorii v movi zhestiv Niderlandiv: rol fonetychnoi realizatsii ta ikonichnosti.

18. Liddell Skott K., Dzhonson Robert E. Amerykanska mova movy: fonolohichna baza. Vyvchennia movnykh znakiv 1989; 64 : 195-277.

19. Sanderl Vendi. Fonolohiia, fonetyka ta bezdohanna ruka. Muton de Hriuiter; Berlin: 2005 r. $185-212$.

20. Padden Karol, Perlmutter Devid M. Amerykanska mova zhestiv ta arkhitektura fonolohichnoi teorii. Pryrodna mova ta movna teoriia. 1987; $5: 335-375$.

21. Raithel, 2000. Rezhym dostupu: http://www.uni-bielefeld.de/lili/personen/vraithel/ teaching/ial/sign-language.pdf

22. Khulst Harri van der. Odynytsi analizu znakiv. Fonolohiia. 1993; 10 : 209-41.

23. Fisher Siuzen, Honh Kunkhu. Poznacheni ruchni konfihuratsii v aziatskykh movakh movy. U: Kanson Reichel, van Harri der Khulst., Formatsiini odynytsi za oznakoiu movy. T. 3. Ishara

24. Shvetski konfihuratsii Rezhym dostupu: http://www.teckensprak.com/handformer.html

25. Modality and Structure in Signed and Spoken Languages, 2009

26. Variation in handshape and orientation in British Sign Language: The case of the "1 hand configuration

27. William C. Stokoe, Dorothy C. Casterline, Carl G. Croneberg Linstok Press, 1976 - 346 r. 